\title{
CREATION OF EDUCATIONAL PRESENTATIONS FROM MATHEMATICS IN TYPESETTING SYSTEM LATEX
}

\author{
Vladimír POLÁŠEK - Lubomír SEDLÁČEK
}

\begin{abstract}
In this paper we deal with making electronic presentations containing mathematical text and created using typesetting system LaTeX. Apart from a brief description of the typesetting system, we present here an overview of basic LaTeX classes, designed to create electronic presentations. As the most sophisticated class, we show Beamer class in more details.
\end{abstract}

Keywords: electronic presentation, mathematical text, TeX, LaTeX, TeXnicCenter, Beamer.

\section{TVORBA VÝUKOVÝCH PREZENTACÍ Z MATEMATIKY V TYPOGRAFICKÉM SYSTÉMU LATEX}

Resumé: $\mathrm{V}$ příspěvku se zabýváme tvorbou prezentací obsahujících matematický text $\mathrm{v}$ typografickém systému LaTeX. Kromě stručného popisu tohoto sázecího systému zde představujeme přehled základních tříd LaTeXu, určených k vytváření elektronických prezentací. Jako nejlépe propracovanou trrídu uvádíme třídu Beamer, které se věnujeme podrobněji.

Klíčová slova: elektronická prezentace, matematický text, TeX, LaTeX, TeXnicCenter, Beamer.

\section{1 Úvod}

Mohutný rozvoj informačních a komunikačních technologií v posledních letech výrazně ovlivnil možnosti publikování a prezentace odborných textů v elektronické podobě. V současné době existuje široká nabídka prezentačních systémů, jejichž použití se velmi rozšířilo ve výuce na školách nebo při prezentacích výsledků vědeckého výzkumu na konferencích. Jsou to např́klad OpenOffice.org Impress, komerční produkt Microsoft PowerPoint nebo MagicPoint pro operační systém Unix. Ne každý z nich však obsahuje prostředky, které umí vytvořit $\mathrm{z}$ typografického hlediska kvalitní prezentaci obsahující matematický text. Při tvorbě prezentace s matematickým obsahem je nutné zvolit program, jenž disponuje nástroji, které dokáží zobrazit matematické grafy, tabulky, vzorce a specifické matematické symboly ve vysoké typografické kvalitě. Mezi takové programy bezesporu patř́ systém LaTeX se svými prezentačními možnostmi třídy Beamer.

\section{Sázecí systém LaTeX}

Typografický systém TeX je volně šiřitelný sázecí program, který je určen pro tvorbu vědeckých, technických, ale i jiných dokumentů. Byl vytvořen koncem sedmdesátých let Ten již obsahuje vysázený text a je pak obvykle zpracován dalším programem na požadovaný cílový formát. Dominantní postavení má výstup v jazyce PostScript, který je díky dvacátého století panem Donaldem Erwinem Knuthem ze Standfordské univerzity, jehož hlavním cílem bylo vytvořit nástroj především pro kvalitní sazbu matematických vztahů. Proto také nachází jedno z největších uplatnění právě při tvorbě matematických textů. Protože práce s tímto programovacím jazykem je velmi náročná a zdlouhavá, byly vytvořeny nadstavby, které umožňují snadnější a přirozenější zápis sázeného textu. Jednou z nejvýznamnějších volně šířených nadstaveb je systém LaTeX, vytvořený $\mathrm{v}$ roce 1985 Leslie Lamportem, jehož hlavní myšlenkou bylo zpř́stupnit poněkud složitý jazyk TeXu běžným uživatelům, kteří nejsou typografičtí profesionálové, a usnadnit jim precizní vysázení požadovaného textu [1]. Systém LaTeX je tedy v podstatě sada maker fungující jako rozšíření systému TeX o mnoho předdefinovaných príkazů. Jsou zde definována např́íklad makra pro strukturování dokumentu, automatizovanou tvorbu obsahu, formátování textu, tvorbu tabulek apod.

Zjednodušeně lze říci, že LaTeX je překladač, který dostane na vstup soubor s textem obsahujícím také príkazy pro sazbu a z těchto údajů vygeneruje soubor typu .dvi (DeVice Independent neboli nezávislý na zařízení).

svým širokým možnostem obecně považován za základní. Dalším užitečným výstupním formátem vhodným pro přenos dat a publikování je PDF (Portable Document Format) firmy Adobe, která 
dodává zdarma pro všechny operační systémy prohlížeče Acrobat Reader. Formát PDF lze získat převodem $\mathrm{z}$ formátu PostScript nebo použitím zvláštního překladače pdfTeX, který místo formátu DVI generuje prrímo formát PDF [1].

Princip práce systému znázorňuje následující schéma:

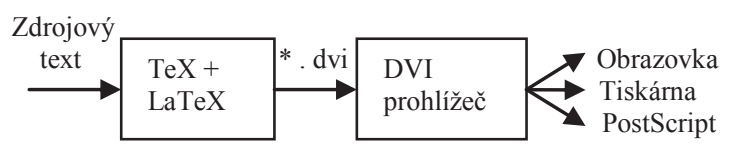

Práce s celým systémem se velmi podobá programování, nebot' obvykle probíhá $\mathrm{v}$ těchto krocích:

1. příprava nebo úprava zdrojového textu,

2. překlad - vysázení,

3. prohlížení.

Tuto posloupnost kroků je třeba opakovat tak dlouho, dokud nedosáhneme požadovaného vzhledu vysázeného dokumentu [1].

Začínajícím uživatelům se může zdát způsob práce $\mathrm{v}$ systému LaTeX náročnější než např́klad ve velmi často použivaném textovém procesoru MS Word od firmy Microsoft. Důvodem může být především to, že většina editorů pro LaTeX, na rozdíl od Wordu, není typu WYSIWYG. Jedná se o akronym anglického slovního spojení "What You See Is What You Get" - co vidíš, to dostaneš. Zkratka označuje způsob editace dokumentů $\mathrm{v}$ počítači, při kterém je verze zobrazená na obrazovce vzhledově totožná $\mathrm{s}$ výslednou verzí dokumentu [2]. Editory pro LaTeX řadíme naopak do kategorie označované WYSIWYM (,What You See Is What You Mean“ - co vidíš, to máš na mysli.). Nevýhodou práce $\mathrm{v}$ těchto editorech je, že v okamžiku psaní zdrojového textu není $\mathrm{k}$ dispozici obraz výsledného dokumentu. Výhodou je, že efektivním zápisem několika potřebných příkazů se systém LaTeX sám postará o precizní, rychlé a bezchybné zpracovaní, vysázení a zobrazení. To např. znamená, že v dokumentu, který píšeme v LaTeXu, se všechny znaky objevují na monitoru ve stejném typu písma a k zvýraznění písma (tučné, kurzíva, apod.) je nutné použít značkovací příkazy [2]. Např́klad věta:

„گ̌Rekneme, že funkce $f$ je hladká na otevřené množině $M$, jestliže má na $M$ spojité všechny parciální derivace.“,

psána ve Wordu, je na monitoru počítače vizuálně totožná s verzí, kterou vytiskneme.
$\mathrm{K}$ vyznačení této věty $\mathrm{v} \mathrm{LaTeXu}$ je však třeba napsat:

„Řekneme, že funkce \$f\$ je

\textit \{hladká\} na otevřené

množině \$M\$, jestliže má na \$M\$

\textbf\{spojité\} všechny

parciální derivace."

Podobně je tomu s matematikou. Matematickou formuli

$$
\lim _{n \rightarrow \infty}\left(1+\frac{1}{n}\right)^{n}
$$

ve zdrojovém kódu LaTeXu zapíšeme jako:

\section{$\$ \$ \backslash \lim n \backslash$ to $\backslash$ infty $\} \backslash \operatorname{left}(1+\backslash$ frac $\{1$ \}$\{n\} \backslash r \bar{i} g h t)^{\wedge}\{n\} \$ \$$.}

Zdrojové soubory LaTeXu lze psát v libovolném textovém editoru, nicméně existuje spousta LaTeX editorů, které tuto práci značně zjednodušují. Nemusíme si pamatovat stovky príkazů a značek LaTeXu, snadno $\mathrm{z}$ menu zvolíme třeba řecká písmena nebo předdefinované styly tabulek a složitějších matematických výrazi̊, funguje i automatické doplňování př́kazů při psaní. Z editorů lze jmenovat třeba WinEdt, TeXnicCenter, WinTex a jiné.

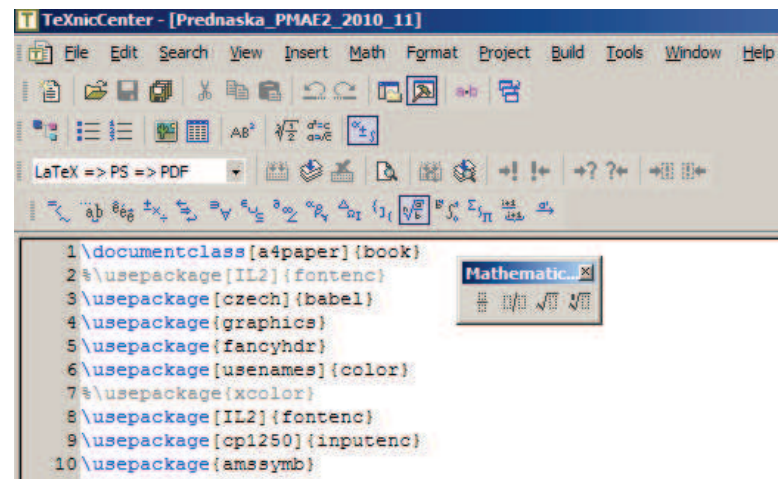

\section{Obr 1: Uživatelské rozhraní editoru} TeXnicCenter

\section{Nástroje LaTeXu pro tvorbu prezentací}

Typografický systém LaTeX již ve své instalaci obsahuje několik rozšiřujících tříd dokumentu typu article či book vhodných pro tvorbu prezentací. Využívá se tak všech vlastností LaTeXu, který obsahuje spoustu předdefinovaných šablon a uživatel se soustředí pouze na samotný obsah prezentace. Výhodou je snadné použití. V některých př́ípadech stačí vzít původní článek, učební text, vymazat nepotřebné pasáže textu a s minimálními modifikacemi 
vytvořit stránky prezentace. Nebo využít vzorových souborů a zaměnit původní text za vlastní. Výsledkem je kvalitně zpracovaný PDF soubor s hladkou sazbou matematických výrazů využívající podobných efektů jako je např. postupné vykreslování snímku, jak je zná běžný uživatel Microsoft Office.

Nyní uvedeme přehled základních tříd LaTeXu pro tvorbu prezentací. Mezi původní třídy patří slides, seminar, př́ip. foils, určené pro tisk průhledných folií, které se zobrazují zpětným projektorem. Talk je další třídou, která umožňuje vytvářet průhledné folie, ale i elektronické prezentace. Na rozdíl od předchozích tříd, které mají pevně daný jednotný vzhled každé stránky prezentace, tato třída dovoluje měnit vzhled jednotlivých stránek libovolně. Jednou $\mathrm{z}$ nejoblíbenějších tříd pro tvorbu prezentací v LaTeXu je prosper. Obsahuje spoustu potřebných nástrojů pro tvorbu kvalitních prezentací, slajdy mohou obsahovat různé přechodové animace, existuje mnoho předdefinovaných stylů, kterými lze snadno měnit vzhled prezentace. Nevýhodou je, že tato třída je postavena na grafickém balíku pstricks, tedy neumožňuje přímý překlad do formátu PDF pomocí pdfLaTeX. Nové možnosti a odstranění některých chyb přinesla třída HAprosper, ale stejně jako prosper už není v této době technicky podporována a na základě těchto dvou vznikla nová třída nazvaná powerdot. Př́mo s pdfLateXem spolupracuje balík TEXPower, který umožňuje překryvy, různé druhy animací, ale práce s ním je obtížnější a nemá předpřipravené styly. Není to třída dokumentu, kompletní prezentační nástroj, ale TEXPower je spíše vhodný pro kombinaci s ostatními třídami, kterým přidává různé dynamické efekty. Vytvářet prezentace podobným způsobem umožňují i balíky pdfslide a pdfscreen. Změní vzhled PDF výstupu původních dokumentů pro čtení na počítačových monitorech. Mění okraje, šiřku a výšku stránky a další parametry, aby se dokument vešel přesně na monitor. Přitom stále lze jednoduše prepínat na původní formát dokumentu podle právě užívané třídy. Zmínit lze třeba i ppower 4 naprogramovaný v jazyce Java, nebo některé další $\mathrm{v}$ operačním systému Unix. Podstatné pro všechny je, že využívají veškeré možnosti systému LaTeX, výstupem jsou kvalitně typograficky i graficky zpracované soubory vhodné pro práci jak na počítači, tak i pro tisk. Nicméně nejlépe propracovanou třídou
LaTeXu pro vytváření prezentací je trrída beamer, o které podrobněji píšeme v další části tohoto článku.

\section{Elektronická prezentace ve truídě Beamer}

Kratší prezentace nebo prezentace bez většího množství matematického textu lze snadněji vytvářet např. pomocí OpenOffice.org, Microsoft Office aj. Pro náročnější uživatele se znalostí LaTeXu lze doporučit třídu beamer, pomocí které lze sestavit elektronické prezentace, běžný článek i tisknout na průhledné folie, vše ve výstupním formátu PDF. Tř́ida beamer umožňuje kontrolu nad rozložením stránek, barvou, písmem, umožňuje dynamické efekty při přechodu mezi jednotlivými stránkami prezentace. Prezentace může obsahovat text, matematiku, grafiku i animace. Využívá se standartních př́kazů LaTeXu, zdrojový kód lze využít i vostatních třídách typu article či book. Snadno se tak z učebního textu stane prezentace a obráceně.

Samotný balík beamer spolu s podrobnou dokumentací [3] je volně stažitelný z internetu, ale je taky součástí distribuce systému LaTeX, která obsahuje i předdefinované šablony a ukázkové prŕíklady. Nejjednodušší způsob, jak začít pracovat s beamerem, je tak využít právě předdefinovaných šablon, kde stačí šablonu zkopírovat do př́slušného adresáře a změnit pouze její obsah. Pomocí šablony nebo jednoduchého ukázkového př́ikladu může i začátečník vytvořit celou řadu prezentací, stačí k tomu znalost prostředí frame, což je ve zdrojovém souboru prezentace označení pro každou jednotlivou stránku. Frame se skládá z několika základních částí, z nichž spousta je volitelných:

- záhlaví a zápatí,

- levostranné a pravostranné pruhy,

- navigační pruhy,

- logo,

- titulek framu,

- pozadí,

- obsah.

Celková podoba a vzhled framu v prezentaci je dána volbou některého $\mathrm{z}$ předdefinovaných stylů. Ty se liší právě tím, jak vypadá záhlaví framu, zda obsahuje boční nebo horní navigační lištu, uspořádáním v navigační liště, liší se barevným stylem a dalšími detaily. Existuje několik způsobů, jak změnit vzhled prezentace. Jednou z možností je využít různé předdefinované styly, v beameru se nazývají themes, kde je předem 
dán např. typ písma, barevné schéma, ale taky třeba styl odrážek ve výčtových prostředích. Zvláštní themes pak jsou jen pro typ písma, pro barvy v prezentaci. Dalšími themes lze např. do framu přidat nebo naopak odebrat navigační lišty, měnit jejich formát a obsah. Možnosti, jak si přizpůsobit vzhled prezentace ve tř́dě beamer, jsou rozsáhlé a není možné je tady do detailů popisovat, není to ani cílem tohoto článku $[3,4]$.

\section{Ukázky prezentací ve trúdě beamer}

V následující části textu popíšeme zdrojový kód jednoduché prezentace a ukážeme výslednou podobu PDF souboru. Dále uvedeme ukázky konkrétních prezentací vytvořených pro výuku matematiky a odbornou konferenci s využitím různých předdefinovaných stylů $\mathrm{s}$ dalšími úpravami podle potřeb autorů.

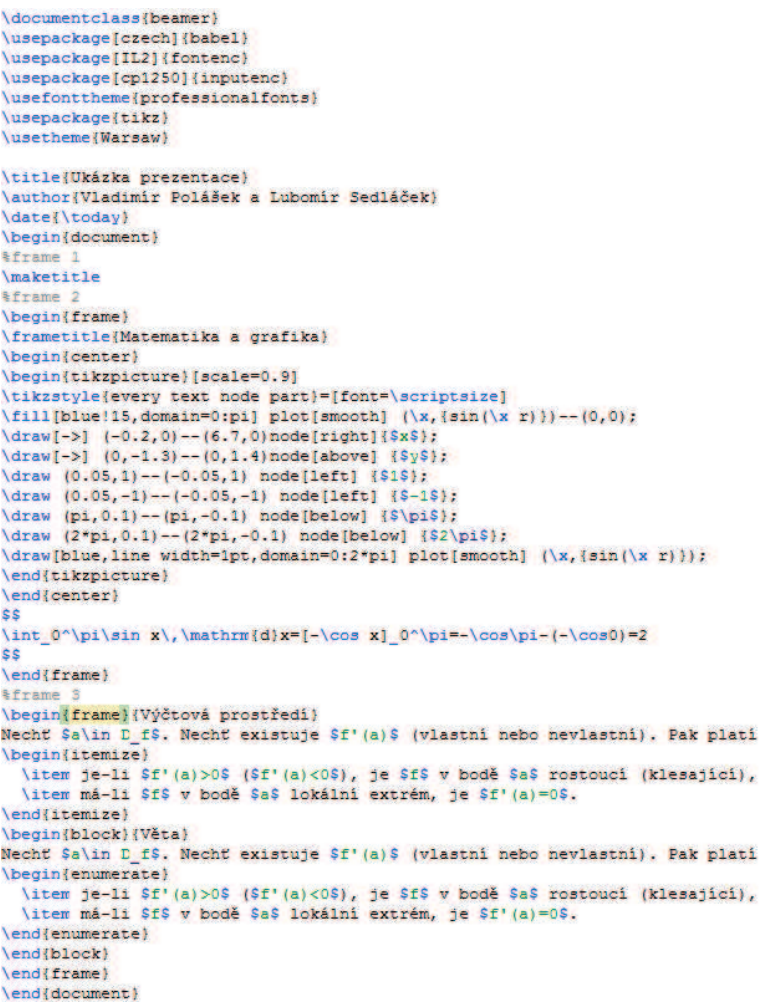

Obr 2: Obsah souboru ukazka.tex

Na Obr. 2 je př́ílad zdrojového kódu krátké prezentace, uložené nap̌r. v souboru ukazka.tex. V preambuli se objevují př́íkazy LaTeXu, kde nejprve je definována třída beamer, tedy formát výstupu oproti article - článek, book kniha. Dále pomocí př́kazu \usepackage volíme různé doplňující balíčky, tedy jakési sady dalších maker a príkazů LaTeXu, v našem př́ipadě pro zavedení českého jazyka, kódování písma a grafický balík tikz. Př́kazem
\usetheme\{Warsaw $\}$ jsme vybrali jeden z předdefinovaných stylů pro celkový vzhled a uspořádání stránek prezentace. Theme Warsaw definuje základní barvy modrou a černou pro záhlaví a zápatí, barva písma je bílá. Zápatí zde standardně obsahuje jména autorů a název článku, ale jeho obsah lze libovolně změnit nebo tento prvek framu úplně odstranit. V pravém dolním rohu framu je navigační lišta pro pohyb v prezentaci (viz Obr. 3, 4, 5). Tělo dokumentu mezi príkazy \begin\{document\} } a \end \{document \} je určeno titulní stránkou, } jejíž obsah se definuje ještě v preambuli a dvěma framy. Každé prostředí frame obsahuje název a obsah, který se objeví na př́slušné stránce prezentace. Ze zdrojového souboru se pak pomocí pdfLaTeXu vytvoří ukázka.pdf, tedy PDF soubor vhodný pro prezentace. Na Obr. 3, 4, 5 lze vidět výsledný výstup, jednotlivé stránky prezentace, které si krátce popíšeme vzhledem ke zdrojovému kódu na Obr. 2. V kódu se vyžívá symbolu „\%“ k vytvoření poznámek, tedy následný text není zpracován při překladu pdfLaTeXem.

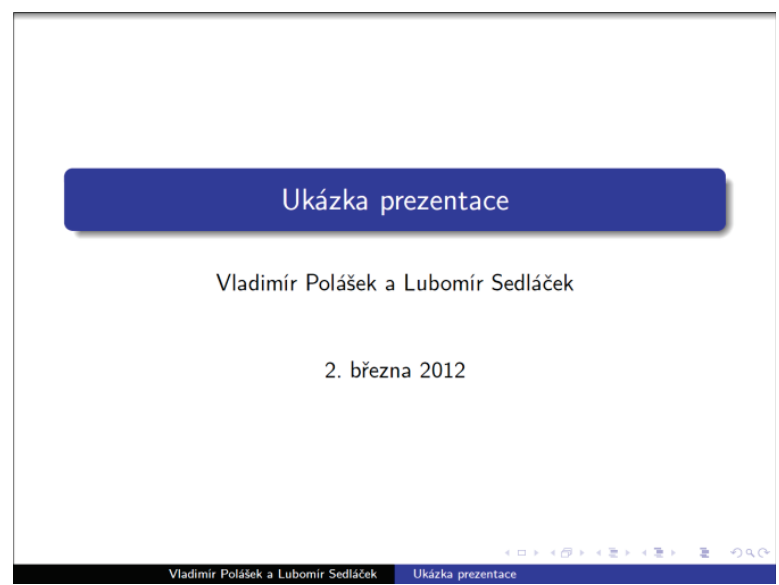

Obr 3: Titulní strana prezentace

Obrázek 3 ukazuje titulní stranu obsahující název prezentace, jména autorů a datum vytvoření dokumentu. Lze doplnit i další informace, např. o autorech, logo instituce a jiné. Titulní strana byla vyvolána př́kazem $\backslash$ maketitle, který ji vytvoří jako samostatnou stranu prezentace bez nutnosti uvozovat v prostředí frame. Balík tikz poskytuje prŕíkazy a makra pro vytváření grafiky prí́mo v dokumentu LaTeXu (na rozdíl od vytváření grafiky vexterních kreslících programech). Je nezávislý na systému, tedy funguje $\mathrm{v} T \mathrm{TeXu}$, LaTeXu aj., a spolupracuje se všemi důležitými překladači TeXu, jako jsou zmiňované pdfLaTeX 
a dvips. Výhodou je práce s príkazy jako u LaTeXu, velmi přesné umíst'ování objektů a kvalitní typografie.

\section{Matematika a grafika}

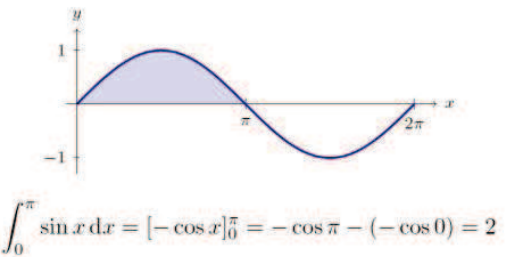

Obr 4: Frame 2 prezentace

Dále Obr. 4 obsahuje matematický text, který je ve zdrojovém kódu ukázkové prezentace zapsán mezi symboly „\$\$“, které současně znamenají jistý styl formátování, tzn. nečíslované rovnice umístěné na střed řádku. Pro jiný styl formátování (číslované rovnice, soustavy rovnic zarovnané do sloupců, atd.) lze volit z prostředí např. equation, align, a dalších.

\section{Výčtová prostředí}

Necht $a \in D_{f}$. Necht existuje $f^{\prime}(a)$ (vlastní nebo nevlastní). Pak platí

- je-li $f^{\prime}(a)>0\left(f^{\prime}(a)<0\right)$, je $f$ v bodě $a$ rostoucí (klesajici).

- má-li $f$ v bodě $a$ lokální extrém, je $f^{\prime}(a)=0$.

\section{Věts}

Necht $a \in D_{f}$. Necht existuje $f^{\prime}(a)$ (vlastní nebo nevlastní). Pak plati

- je-li $f^{\prime}(a)>0\left(f^{\prime}(a)<0\right)$, je $f$ v bodě $a$ rostouci (klesajici)

- má-li $f$ v bodě $a$ lokálni extrém, je $f^{\prime}(a)=0$.

\section{Obr 5: Frame 3 prezentace}

Nedílnou součástí matematického textu i samotných prezentací jsou tzv. výčtová prostředí. Slouží jednak k výpisu vlastností např. funkce, důsledků nějakého tvrzení apod., ale taky k uspořádání informací tak, aby posluchač snadněji sledoval výklad. Poslední strana prezentace (Obr. 5) ukazuje prostý a číslovaný výčet, vytvořené pomocí prostředí itemize a enumerate. U těchto prostředí lze nadefinovat postupné odkrývání jednotlivých bodů, a to nejen za sebou, ale i v libovolném pořadí. Výsledkem bude jeden frame skládající se z několika slajdů, tzn. více stran prezentace. $\mathrm{Na}$ Obr. 5 si ještě všimněme rámečku s názvem, jde o prostředí block sloužící k oddělení specifických částí textu od zbytku framu, napřr. k zvýraznění důležitých tvrzení.

Ukázková prezentace obsahuje základní prvky, které prezentace zejména $\mathrm{z}$ matematiky běžně obsahují. Jde o matematický text psaný odlišným typem písma, grafy funkcí, výčtová prostředí, rámečky pro zvýraznění textu. V následujícím odstavci uvedeme několik ukázek prezentací, které vznikly pro potřeby výuky matematiky, a ukazující variabilitu třídy Beamer.

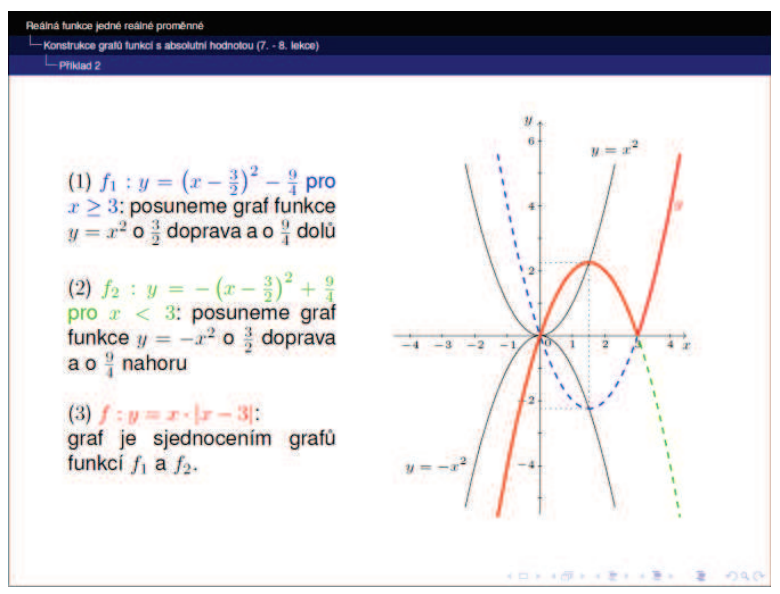

Obr 6: Varianta |usetheme\{Antibes\}

Obrázek 6 je ukázkou framu z prezentace pro střední školy vytvořené ve stylu Antibes. Protože text je členěn na kapitoly a podkapitoly, Antibes vkládá do záhlaví název prezentace, kapitoly i odpovídající podkapitoly, což pomáhá $\mathrm{k}$ lepší orientaci $\mathrm{v}$ textu. Zde frame neobsahuje název, ten by zvětšil plochu záhlaví a obsah framu by se už nevešel na výšku obrazovky. Samotný obsah framu je členěn do dvou sloupců. V levém se po krocích odkrývá postup na vykreslení grafu a v pravém sloupci se graf vykresluje. Postupné odkrývání napomáhá přednášejícímu lépe vysvětlit jednotlivé kroky.

Obrázek 7 ukazuje slajd z prezentace pro odbornou konferenci z matematiky. Je vytvořena pomocí theme Frankfurt. Jeden z rozdílů od předchozího stylu vidíme při členění záhlaví, zde obsahuje i název framu a přitom zabírá téměř stejnou plochu a tedy na obrazovku se vejde stejné množství textu, případně dalšího obsahu. 


\section{Carathéodory conditions}

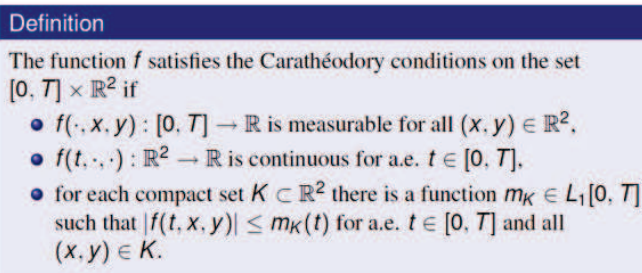

Obr 7: Varianta |usetheme\{Frankfurt\}

Pokud je prezentace obsáhlejší, lze názvy kapitol, podkapitol, odstavců zobrazit v levém nebo pravém pruhu vedle textu.

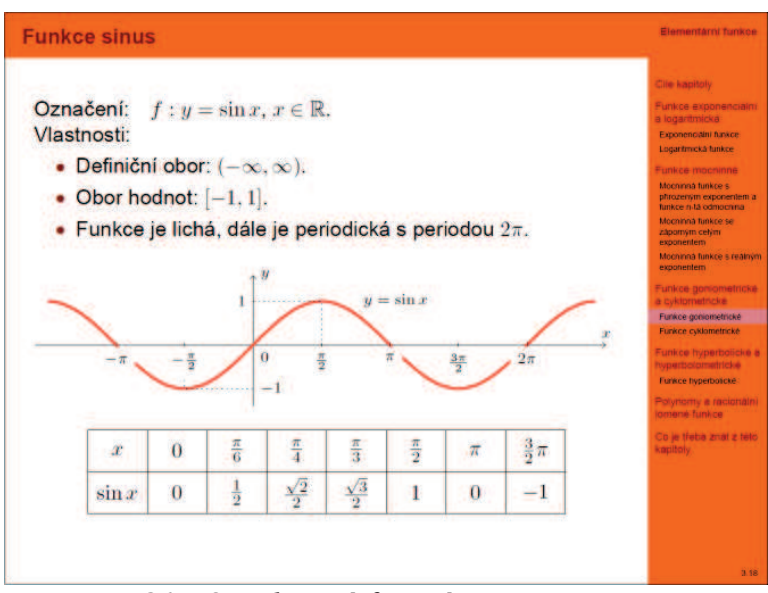

Obr 8: Vlastní formát prezentace

Formát prezentace na Obr. 8 vytvořil autor dle vlastních potřeb, tedy změna základní barvy, uspořádání v postranní liště a další detaily. Ve srovnání s předchozími formáty, boční lišta zúží šířku framu a je nutné dbát na to, aby se text do framu vešel na šiřku obrazovky.

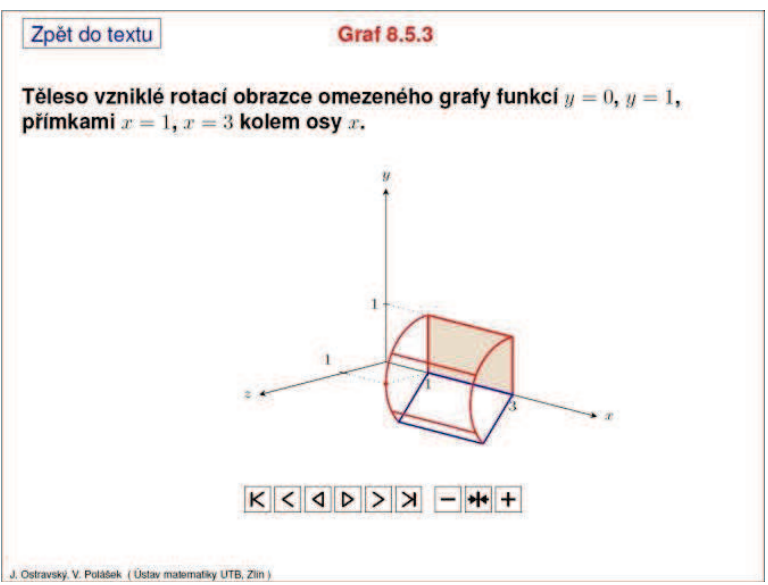

Obr 9: Jednoduchý formát prezentace
Poslední obrázek (Obr. 9) je z prezentace, která se skládá pouze $\mathrm{z}$ jednoho framu, a slouží jako doplňující prezentace $\mathrm{k}$ hlavnímu učebnímu textu. V záhlaví je vytvořen hypertextový odkaz pro návrat zpět do učebního textu bez nutnosti uzavírat PDF soubor prezentace. Zajímavým prvkem této prezentace je animace představující rotaci obdélníku kolem osy vytvořená prrímo v LaTeXu.

\section{Závěr}

Třída beamer systému LaTeX je určena zejména náročnějšímu uživateli, který klade důraz na vysokou strukturální úroveň a typografickou přesnost prezentovaného textu. Díky zabudovaným typografickým pravidlům a předdefinovaným stylům formátování bude výsledkem jeho práce typograficky kvalitně zpracovaný PDF formát. Při tvorbě prezentace se využívá všech vlastností systému LaTeX, jakožto mocného nástroje pro sazbu složitějších matematických vztahů. Díky tomu je príprava prezentace pro uživatele ovládající alespoň základy LaTeXu snadná a pohodlná.

\section{Literatura}

[1] RYBIČKA, J. LaTeX pro začátečníky. 3. vydání. Brno: Konvoj, 2003. 238 s. ISBN 807302-049-1.

[2] GRÄTZER, G. What Is New in LATEX? IV. WYSIWYG LATEX. Notices of the American Mathematical Society. 2011, Vol. 58, no. 6.

[3] TANTAU, T., WRIGHT, J., MILETIĆ, V. User's guide (online). 2003 $\div 2011$ [cit. 2012-03-

10]. URL: $<$ http://www.ctan.org $>$.

[4] MERTZ, A., SLOUGH, W. Beamer by Example. The PracTEX Journal, 2005, no. 4.

Mgr. Vladimír Polášek, Ph.D.

Mgr. Lubomír Sedláček, Ph.D.

Ústav matematiky

Fakulta aplikované informatiky

Univerzita Tomáše Bati ve Zlíně

Nad Stráněmi 4511

76005 , Zlín, ČR

Tel: +420 576035057

E-mail: vpolasek@fai.utb.cz,

Isedlacek@fai.utb.cz

Www pracoviště: www.fai.utb.cz 